\title{
KORELASI ANTARA PEMBELAJARAN FULL DAY SCHOOL DENGAN KARAKTER PEDULI SOSIAL SISWA SMP IT HIDAYATULLAH KOTA BENGKULU DAN IMPLIKASI BIMBINGAN DAN KONSELING
}

\author{
Dianayu Ambarsari, Hadiwinarto, Anna Ayu Herawati \\ Prodi Bimbingan dan Konseling Fakultas Keguruan dan Ilmu Pendidikan \\ Universitas Bengkulu \\ ambarsaridianayu04@gmail.com, hadiwin@unib.ac.id, annaayuherawati@unib.ac.id
}

\begin{abstract}
ABSTRAK
Full day school merupakan pilihan untuk mengatasi berbagai persoalan pendidikan, baik secara akademis maupun dari segi moralitas dan karakter. Tujuan dari penelitian ini adalah untuk melihat apakah ada hubungan antara pembelajaran full day school dan karakter peduli sosial siswa. Penelitian ini menggunakan metode korelasional untuk melakukan penelitian deskriptif kuantitatif. Populasi dalam penelitian ini adalah 85 siswa dari SMP IT Hidayatullah Kota Bengkulu pada kelas VII, VIII, dan IX. Sampel penelitian terdiri dari 46 siswa yang diambil dari seluruh kelas VII, VIII, dan IX dengan bantuan statified random sampling. Instrumen pembelajaran full day school memiliki reliabilitas 0,788 , sedangkan instrumen karakter peduli sosial memiliki reliabilitas 0,759. Dengan rxy 0,448 dan tingkat signifikan 0,002 (p0,05), temuan mengungkapkan hubungan yang kuat antara pembelajaran pembelajaran full day school dan karakter peduli sosial. Hal ini menunjukkan bahwa ada hubungan antara pembelajaran full day school dengan karakter peduli sosial.
\end{abstract}

Kata Kunci: Pembelajaran Full Day School, Karakter Peduli Sosial

\section{CORRELATION BETWEEN FULL DAY SCHOOL LEARNING WITH SOCIAL CARE CHARACTERS OF STUDENTS OF IT HIDAYATULLAH SMP BENGKULU CITY AND IMPLICATIONS OF GUIDANCE AND COUNSELING}

\begin{abstract}
ABSTRACK
It is a full-day school an option to solve a variety of educational issues, both academically and when it comes to morality and character. The purpose of this study was to see whether there had been a relationship between full day schooling and after-school activities social care character of students. This study uses a correlational approach to conduct descriptive quantitative research this study's participants were 85 students from SMP IT Hidayatullah Bengkulu City in grades VII, VIII, and IX. The research sample consisted of 46 students taken from all grades VII, VIII, and IX using statified random sampling technique. The full day school learning the instrument offers a high level of dependability 0.788 , while the social care character the instrument offers a high level of dependability. 0.759. With an rxy of 0.448 and a significant level of 0.002 (p0.05), the findings reveal a considerable positive association between the two variables full day school learning and social care characters. This shows that there is a relationship between full day school learning and social care characters.
\end{abstract}

Keywords : Full Day School Learning, Social Care Character 


\section{PENDAHULUAN}

Pendidikan adalah alat yang dapat digunakan dalam berbagai cara untuk mengembangkan generasi masa depan yang berkualitas. Pendidikan adalah upaya menciptakan lingkungan belajar dimana siswa secara aktif mengembangkan potensi kepribadiannya yang baik, akhlak yang baik sebagai pribadi yang unik, kecerdasan, kekuatan spiritual agama dalam berbagai hal, serta kemampuan yang dibutuhkan bagi dirinya sendiri, lingkungan sekitar secara keseluruhan (Rizky, 2019:441).

Pendidikan karakter adalah pendidikan karakter plus, menurut Zubaidi (dalam Cindy, 2011:25), ini adalah pendekatan pengajaran yang mencoba meningkatkan karakter siswa dengan menanamkan nilai-nilai dan kepercayaan masyarakat sebagai kekuatan moral dalam kehidupan mereka. kejujuran, ketergantungan, disiplin diri dan kerjasama. Dalam hal ini sama artinya dengan membantu siswa membentuk karakter pada diri siswa. Pada dasarnya membentuk karakter memerlukan waktu yang cukup lama karena sama halnya membentuk kebiasaan. Seperti pendapat Amri dkk, (2011:85) selama pelaksanaan disekolah, peran guru sangat penting dalam pengembangan karakter. Nilai-nilai agama dalam pembelajaran berdampak besar pada pendidikan karakter karena nilai-nilai agama harus tertanam dalam benak anak-anak agar mereka memiliki sense of self yang kuat. Terbukti bahwa siswa dapat membentuk dirinya dalam kehidupan sehari-hari berdasarkan lingkungan yang ditemui dan diamatinya.

Karena setiap orang memiliki interaksi sosial dengan individu atau kelompok lain, mereka adalah makhluk sosial. Sebagai makhluk sosial membutuhkan bantuan dari yang lain, lebih baik seorang dengan sukarela membantu orang lain. Kepedulian sosial adalah sikap seseorang terhadap makhluk sosial dimana mereka peduli terhadap orang lain. Tujuan merawat orang lain adalah untuk meringankan penderitaan atau kesusahan mereka sehingga individu dapat menerima bantuan dengan semua kesulitannya. Lingkungan terdekat seseorang berdampak pada terciptanya kepedulian sosial seseorang. Karena setiap orang memiliki hubungan sosial dengan orang atau kelompok lain, mereka disebut sebagai makhluk sosial. Sebagai makhluk sosial yang membutuhkan bantuan dari orang lain, lebih baik seorang manusia dengan sukarela membantu. Peduli sosial adalah istilah untuk jenis kegiatan membantu. Istilah "kepedulian sosial" mengacu pada sikap yang ada dalam diri seseorang untuk peduli sesama terhadap makhluk sosial. Tujuan merawat orang lain adalah untuk meringankan penderitaan atau kesulitan mereka sehingga mereka dapat mengatasi masalah mereka dengan lebih baik, lingkungan terdekat adalah yang berpengaruh dalam pembentukan kepedulian sosial seseorang. Lingkungan terdekat itu 
sendiri yaitu, keluarga, teman-teman, sahabat, lingkungan masyarakat dan lingkungan sekolah. Namun seiring perkembangan zaman nilai kepedulian sosial semakin luntur. Misalnya banyak orang yang tidak peduli lagi dengan lingkungannya seperti, tidak mau membantu sesama makhluk sosial, tidak setia kawan dan mau menang sendiri. Penyebab lunturnya sikap peduli sosial didasari oleh sikap egois dan kurangnya simpati dan empati.

Clark \& Kirk (2000:85) mengemukakan bahwa "because of the benefits and drawbacks within the community, the full day school policy's implementation should be thoroughly examined". Ini berarti bahwa beberapa orang percaya bahwa sekolah sehari penuh dapat membuat siswa tertekan karena banyaknya pekerjaan yang harus mereka lakukan. Selain itu, mereka harus menggunakan waktu belajar yang efektif dan pengajaran yang terencana untuk menciptakan peluang belajar ketika menerapkan sekolah sehari penuh. Ada sebagian siswa tidak setuju karena merasa lelah, mengantuk dan jenuh sehingga kegiatan kelas dan pembelajaran siswa kurang kondusif. Berdasarkan (Lynch, M, 2014: 85) "the full day school policy is being implemented very interesting to be studied carefully because of the pros and cons among the community'. Artinya penerapan kebijakan full day School sangat menarik untuk dikaji secara seksama karena adanya pro dan kontra di kalangan masyarakat. Selanjutnya full day schoolberdasarkan program keseimbangan antara kognitif, emosional, sosial, dankemampuan spiritual dianggap program yang sangat baik, karena membuat waktu belajar siswa menjadi efektif danmemaksimalkan potensi siswa.

Penggunaan full day school dalam pembentukan karakter anak mendapat respon yang baik, terbukti secara spiritual/psikis dapat membentuk karakter siswa, khususnya kepedulian sosial, ikhlas, disiplin, dan akuntabel (Leasa \& Batlolona, 2017:3). Penelitian ini terdapat banyak contoh kasus yang membahas tentang rendahnya karakter siswa seperti, sikap orang tua yang menentang karena sudah memiliki pola pikir sendiri, kurang peduli dengan lingkungan sekolah seperti (gotong royong, piket kelas dan lai-lain), membolos dan keluar dari jam pelajaran dikelas, tidak memiliki perilaku sopan santun dan perilaku budi pekerti. Selama kegiatan sekolah full day school siswa yang biasanya waktunya lebih banyak digunakan di lingkungan keluarga dan masyarakat harus tersita karna adanya full day school yang menyebabkan terjadinya kurang interaksi dalam lingkungan keluarga dan masyarakat. sehingga kepedulian sosial mereka hanya fokus terhadap lingkungan sekolah.

Lebih lanjut Zubaedi (2011: 13) menunjukkan, pelaksanaan pendidikan karakter terdiri dari beberapa komponen, termasuk informasi moral, perasaan moral, dan perilaku 
moral semuanya saling terkait. Mengetahui apa yang baik, menginginkan apa yang baik, dan melakukan apa yang baik adalah semua komponen dari perilaku yang baik. Dalam hal ini, pembiasaan berpikir serta pembiasaan tindakan diperlukan. Pengembangan karakter melalui layanan bimbingan dan konseling memiliki keunggulan sebagai berikut: siswa menjadi lebih mandiri dalam memecahkan masalah, siswa menjadi lebih mampu menerapkan sopan santun di antara teman dan masyarakat, siswa menjadi lebih menghargai setiap proses pembelajaran yang ditemuinya baik di rumah maupun di sekolah, siswa berkembang menjadi lebih bisa menerapkan sopan santun tata krama.

Studi pendahuluan yang dilakukan di SMP IT Hidayatullah Kota Bengkulu yang ditemukan dilapangan terdapat beberapa siswa yang sekolah full day dimana sekolah tersebut dimulai dari pagi hingga sore. Pengamatan yang dilakukan dalam kegiatan sekolah 10 (sepuluh) jam penuh banyak siswa yang sangat peduli dengan lingkungan dan orang sekitar. Dapat dilihat ketika ada kegiatan kebersihan kelas atau gotong royong, siswa selalu antusias untuk ikut bekerja membersihkan lingkungan sekolahnya. Adapun atau tidaknya guru mengawasi mereka saling bahu membahu membersihkan kelas dan sekelilingnya. Ada juga ketika seseorang yang sedang membutuhkan pertolongan mereka pun membantunya. Tetapi ada juga siswa yang bosan dan kurang peduli dengan lingkungan sekitarnya.

Berdasarkan studi pendahuluan dilapangan sebelumya, peneliti menjadi tertarik dan berusaha melakukan penelitian guna untuk mengetahui rasa kepedulian sosial siswa dikalangan sekolah yang menggunakan sistem pembelajaran full day school sehingga peneliti dapat melihat masalah yang dihadapi, dengan ini peneliti melakukan penelitian tentang "korelasi antara pembelajaran full day school dengan karakter peduli sosial siswa SMP IT Hidayatullah Kota Bengkulu dan implikasi bimbingan dan konseling” .

\section{METODE PENELITIAN}

Studi ini menggabungkan metodologi kuantitatif dan korelasional. Metodologi korelasi adalah suatu metode untuk menentukan adanya hubungan antara dua variabel Darmadi (2014: 206). Besarnya hubungan antara pembelajaran full day school dengan karakter peduli sosial siswa SMP IT Hidayatullah Kota Bengkulu ditentukan dengan menggunakan pendekatan korelasional.

Populasi pada penelitian ini adalah siswa kelas VII,VIII, IX SMP IT Hidayatullah Kota Bengkulu yang jumlah keseluruhannya adalah 85 siswa. Metode penelitian ini adalah stratified random sampling, yaitu membagi populasi ke dalam berbagai tingkatan atau 
kelas. Beberapa sampel dipilih secara acak atau random dari berbagai kelas Notoatmojo (2005:25). Dalam penelitian ini peneliti menetapkan 35 siswa sebagai sampel uji coba dan 46 siswa sebagai sampel penelitian. Penelitian ini menggunakan instrumen berupa angket/kuisoner untuk mengetahui tingkat karakter peduli sosial dengan cara diukur dengan menggunakan model skala Likert.

Uji Validitas kuisioner dilakukan dengan dua pengujian yaitu uji validitas isi yang melibatkan ahli dan uji coba yang melibatkan siswa bukan kelas sampel. Berdasarkan hasil uji validitas isi dari angket pembelajaran full day school oleh ahli diperoleh 56 butir item valid dari 60 butir item pada instrumen. Dengan adanya perbaikan beberapa butir instrument. Selanjutnya hasil uji validitas isi dari angket karakter peduli sosial oleh ahli diperoleh 68 butir item yang valid dari 70 butir item pada instrument. Selanjutnya diuji coba kan ke kelas yang bukan merupakan kelas sampel, yaitu 3 kelas yang diantaranya adalah kelas VII, VIII, IX yang berjumlah 85 orang siswa. Uji validitas tiap item pernyataan dilakukan dengan menggunakan aplikasi komputer SPSS khususnya pendekatan korelasi product moment.

Uji reliabilitas menentukan apakah kuesioner penelitian akan digunakan untuk mengumpulkan data untuk variabel penelitian dapat dipercaya atau tidak. Menurut Sumadi (2004:28) kuesioner tersebut dapat diandalkan karena jika diukur kembali hasilnya akan sama. Uji reliabilitas dinyatakan reliabel yaitu apabila nilai alpha lebih besar dari 0,7. Pada hasil uji reliabilitas pembelajaran full day school menunjukkan alpha cronbach's sebesar 0,788 dan hasil uji reliabilitas karakter peduli sosial menunjukkan alpha Cronbach's sebesar 0,759 sehingga dapat disimpulkan bahwa instrument kuisoner pada penelitian ini diterima atau reliable.

\section{HASIL DAN PEMBAHASAN}

Berdasarkan hasil analisis diperoleh hasil gambaran pembelajaran fullday school melalui tabel 1 di bawah ini.

Tabel 1. Deskripsi Pembelajaran Full Day School

\begin{tabular}{lc}
\hline Jumlah sampel $(\mathrm{N})$ & 46 \\
\hline Skor Minimum & 56 \\
Skor Maximum & 280 \\
Rata-rata $(\mu)$ & 168 \\
\hline Standar Deviasi $(\sigma)$ & 37 \\
\hline
\end{tabular}

Dari table tersebut diketahui bahwa gambaran tentang pembelajaran full day 
school dengan skor minimal 56, skor maksimal 280, rata-rata 168, dan standar deviasi 37. Skor tersebut dikategorikan ke dalam lima kategori pembelajaran full day school yaitu: sangat tinggi, tinggi, sedang, rendah, dan sangat rendah dalam tabel 2 berikut.

Tabel 2. Kategorisasi data Pembelajaran full day school

\begin{tabular}{lccc}
\hline Kategori & Rentang Skor & Frekuensi & Presentase (\%) \\
\hline Sangat Tinggi & $>223$ & 1 & $2,1 \%$ \\
Tinggi & $186-222$ & 8 & $17 \%$ \\
Sedang & $149-185$ & 32 & $69 \%$ \\
Rendah & $112-148$ & 4 & $8,6 \%$ \\
Sangat Rendah & $<111$ & 1 & $2,1 \%$ \\
\hline Total & & 46 & $100 \%$ \\
\hline
\end{tabular}

Dapat dilihat dari tabel 2 bahwa subjek pembelajaran full day school berada pada kategori sangat tinggi, dengan frekuensi 1 siswa, atau dapat disajikan nilai $(2,1 \%)$. Selanjutnya terdapat 6 siswa dalam kategori frekuensi tinggi yang dapat disajikan dengan nilai (13\%), 36 siswa dalam kategori sedang yang dapat disajikan dengan nilai (78\%), dan 3 siswa dalam kategori rendah yang dapat disajikan dengan nilai (6,5\%).Dan tidak ada tingkat subjek pembelajaran full day school berada pada kategori sangat rendah. Kemudian memiliki skor rata-rata 168 yang berkategori sedang. Selanjutnya, ringkasan skor karakter peduli sosial dihitung sesuai dengan skor optimal dapat dilihat pada Tabel 3.

\section{Tabel 3 Deskripsi Karakter Peduli Sosial}

\begin{tabular}{lc}
\hline Jumlah sampel $(\mathrm{N})$ & 46 \\
\hline Skor Minimum & 68 \\
Skor Maximum & 340 \\
Rata-rata $(\mu)$ & 204 \\
Standar Deviasi $(\sigma)$ & 45 \\
\hline
\end{tabular}

Berdasarkan tabel 3 diperoleh deskripsi karakter peduli sosial dengan skor minimal 68, skor maksimal 340, rata-rata 204, dan standar deviasi 45. Kategorisasi lebih lanjut dilakukan berdasarkan peringkat ini. Subyek dibagi menjadi lima kategori berdasarkan karakteristik kepedulian sosialnya: sangat tinggi, tinggi, sedang, rendah, dan sangat rendah. Standar deviasi dan mean digunakan untuk menentukan kategori ini dalam tabel 4. 
Tabel 4 Kategorisasi Karakter Peduli Sosial

\begin{tabular}{cccc}
\hline Kategori & Rentang Skor & Frekuensi & Presentase (\%) \\
\hline Sangat Tinggi & $>271$ & 1 & $2,1 \%$ \\
Tinggi & $226-270$ & 3 & $13 \%$ \\
Sedang & $181-225$ & 34 & $73 \%$ \\
Rendah & $136-180$ & 8 & $17 \%$ \\
Sangat Rendah & $<135$ & 0 & $0 \%$ \\
\hline Total & & 46 & $100 \%$ \\
\hline
\end{tabular}

Tabel 4 menunjukkan karakter peduli sosial kategori sangat tinggi memiliki frekuensi 1 siswa atau dapat dinyatakan dengan nilai $(2,1 \%)$. Selanjutnya suatu nilai (13\%) dapat disajikan dalam kategori tinggi dengan jumlah frekuensi 3 siswa, dan nilai dapat disajikan dalam kategori sedang dengan jumlah frekuensi 34 siswa (73 persen). Selanjutnya kategori rendah memiliki frekuensi sebanyak 8 siswa atau nilai (17\%), dan tidak ada siswa yang memiliki kategori karakter peduli sosial sangat rendah. Pada kategori sedang, memiliki skor rata-rata 204.

Untuk mengetahui hubungan antara kedua variabel digunakan hasil pengujian hipotesis, dan sejauh mana hubungan kedua variabel tersebut, yaitu pembelajaran full day school dengan karakter peduli sosial. Paket Statistik untuk Ilmu Sosial (SPSS) untuk Window Release 16.00 Product Moment digunakan untuk mengevaluasi hipotesis korelasi Product Moment Pearson.

Tabel 5. Korelasi Pembelajaran Full Day School dengan Karakter Peduli Sosial

\begin{tabular}{|c|c|c|c|}
\hline \multicolumn{4}{|c|}{ Correlations } \\
\hline & & $\begin{array}{l}\text { PEMBELAJARAN } \\
\text { FULL DAY SCHOOL }\end{array}$ & $\begin{array}{l}\text { KARAKTER PEDULI } \\
\text { SOSIAL }\end{array}$ \\
\hline $\begin{array}{l}\text { PEMBELAJAR } \\
\text { AN FULL DAY } \\
\text { SCHOOL }\end{array}$ & $\begin{array}{c}\text { Pearson } \\
\text { Correlation } \\
\text { Sig. (2-tailed) }\end{array}$ & 1 & $\begin{array}{l}, 448^{* *} \\
, 002\end{array}$ \\
\hline $\begin{array}{l}\text { KARAKTER } \\
\text { PEDULI } \\
\text { SOSIAL }\end{array}$ & $\begin{array}{c}\mathrm{N} \\
\text { Pearson } \\
\text { Correlation } \\
\text { Sig. (2-tailed) }\end{array}$ & $\begin{array}{c}46 \\
, 448^{* *} \\
, 002\end{array}$ & $\begin{array}{c}46 \\
1\end{array}$ \\
\hline & $\mathrm{N}$ & 46 & 46 \\
\hline
\end{tabular}

Berdasarkan hasil perhitungan korelasi antara pembelajaran full day school dengan karakter peduli sosial dapat dinyatakan bahwa korelasi person $\left(r x_{y}\right)$ memeliki korelasi yang signifikan 0,448, meningkatkan tingkat signifikansi 0,002 $(\mathrm{p}<0,05)$. Jika nilai $\mathrm{p}<0,05$ maka Ho ditolak, berarti Ha disetujui.

Dapat dikatakan bahwa ada hubungan yang kuat antara keduanya yang signifikan dan positif antara kedua variabel pembelajaran full day school dengan karakter peduli 
sosial yang artinya semakin tinggi pembelajaran full day school maka akan semakin tinggi pula karakter peduli sosial siswa. Demikian juga sebaliknya semakin rendah pembelajaran full day school maka semakin rendah pula karakter peduli sosial siswa. Namun, pada sebagian besar level pembelajaran full day school dengan karakter peduli sosial berada dalam kategori sedang. Diferensiasi berdasarkan kategori pembelajaran full day school dengan karakter peduli sosial setiap individu memiliki kemampuan diri yang berbeda, setiap individu memiliki pembelajaraan full day school yang berbeda-beda sesuai dengan faktor dari diri siswa itu sendiri. Jika pembelajaran full day school tinggi maka karakter peduli sosial siswa meningkat atau baik. Hal ini sejalan dengan temuan penelitian Baharuddin (2010:227) yang menemukan bahwa Seiring perkembangan siswa melalui sekolah sehari penuh karakternya akan berkembang. Leasa \& Batlolona (2017: 45) melakukan penelitian serupa, yang menemukan bahwa penerapan nilai-nilai budi pekerti dan akhlak mulia pada siswa akan diperkuat dengan full day school. Hal ini didukung oleh penelitian Yusuf (2017:28) yang menunjukkan bahwa kurikulum full day school bermanfaat bagi pengembangan karakter siswa.

Tidak mudah untuk meningkatkan dan membentuk karakter seseorang. Dibutuhkan banyak usaha dari banyak orang untuk mewujudkannya. Pengembangan karakter tidak dapat dipisahkan dari pendidikan. Pembentukan karakter generasi muda dapat dimulai di lingkungan sekolah, karena pendidikan formal berperan penting dalam pembentukan karakter generasi muda sejak dini. Konsepsi moral, sikap moral, dan tindakan moral adalah semua aspek penting dalam kehidupan. Karakter yang baik dapat didefinisikan sebagai pengetahuan tentang kebaikan, keinginan untuk berbuat baik, dan melakukan perbuatan baik berdasarkan tiga komponen ini. Ketiganya dituntut untuk menjalani kehidupan yang layak dan mengembangkan kedewasaan moral pada diri siswa Lickona (1991:51). Hasil penellitian yang dilakuukan di SMP IT Hidayatullah Kota Bengkulu menunjukkan pembelajaran full day school dengan karakter peduli sosial sedang. Hal ini menunjukkan semakin baik karakter peduli sosial siswa, semakin banyak full day school yang diterimanya. Sebaliknya, semakin rendah karakter peduli sosial seorang siswa, maka semakin rendah pula pembelajaran full day school.

\section{KESIMPULAN}

1. Tingkat pembelajaran full day school siswa kelas VII, VIII, IX SMP IT Hidayatullah Kota Bengkulu tergolong sedang,

2. Tingkat karakter peduli sosial siswa kelas VII, VIII, IX SMP IT Hidayatullah Kota Bengkulu tergolong sedang. 
3. Pembelajaran full day school dan karakter peduli sosial siswa SMP IT Hidayatullah Kota Bengkulu memiliki hubungan yang positif. dapat dinyatakan bahwa memiliki korelasi yang signifikan 0,448 dengan tingkat signifikan 0,002 ( $\mathrm{p}<0,05)$. Artinya, semakin tinggi antara pembelajaran full day school yang dimiliki siswa maka semakin tinggi karakter peduli sosial siswa dan sebaliknya.

\section{DAFTAR PUSTAKA}

Amri, dkk. 2011. Implementasi karakter dalam pembelajaran. Jakarta: PT Pustaka

Baharuddin. 2010. Pendidikan dan Psikologi Perkembangan. Jogjakarta: Ar-Ruzz Media

Clark, P.,\&Kirk,E.(2000). Efektifitas Sistem Full Day School. Jurnal Manageen Pendidikan. Vol 13, No 1: hal 24-33

Darmadi, Hamid. (2014). Metode penelitian pendidikan sosial. Bandung: Alfabet

Leasa, Marleny \& Batlolona, John Rafafy. "Full Day School Dalam Pembentukan Karakter Siswa SMK N 13 Kota Malang”. Jurnal Ilmu Sosial dan Humaniora. Vol. 6 (1): hal: 73-82

Lickona, T. (2013). Educating for Character: Mendidik Untuk Membentuk Karakter (Terjemahan). Jakarta: Bumi Aksara

Lynch, M.(2014). Full Day School Dalam Diskusi Media Sosial. Jurnal Pendidikan edukasi sains. Vol 49 (2): hal 329-347

Notoatmodjo, Soekidjo. (2005). Metodologi Penelitian Kesehatan. Jakarta: PT Rineka Cipta

Rizky \& Umbu, Tagelar (2019). Penggunaan Layanan Bimbingan Kelompok Dalam Meningkatkan Kepedulian Sosial Siswa Kelas XI Bahasa SMA Kristen Satya Wacana Salatiga Tahun 2018/2019. Jurnal Psikologi Konseling Vol. 15 No. 2, Desember 2019

Yusuf. 2017. Full Day School: Proses implementasi model keunggulan sekolah untuk pendidikan yang baik. Jurnal Global Citizen. Vol 1, Nomor 1, April 2017

Zubaedi. 2011. Desain Pendidikan Karakter: Konsepsi dan Aplikasinya dalam Lembaga Pendidikan. Jakarta: Kencana 